\section{Diamond forms during low pressure serpentinisation of oceanic lithosphere}

\author{
N. Pujol-Solà ${ }^{1 *}$, A. Garcia-Casco ${ }^{2,3}$, J.A. Proenza ${ }^{1,4}$, J.M. González-Jiménez ${ }^{2}$, \\ A. del Campo ${ }^{5}$, V. Colás ${ }^{6}$ À. Canals ${ }^{1}$, A. Sánchez-Navas ${ }^{2}$, J. Roqué-Rosell ${ }^{1,4}$
}

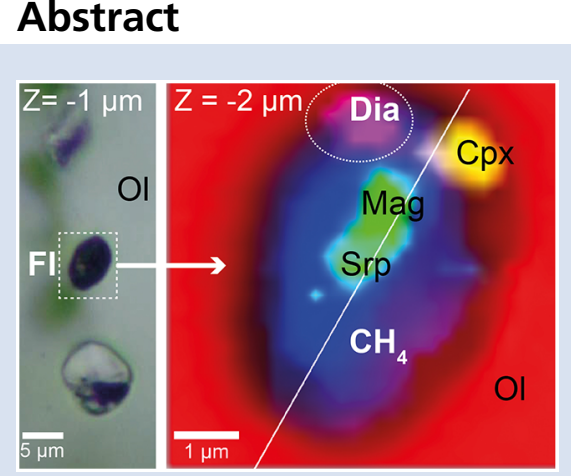

Diamond is commonly regarded as an indicator of ultra-high pressure conditions in Earth System Science. This canonical view is challenged by recent data and interpretations that suggest metastable growth of diamond in low pressure environments. One such environment is serpentinisation of oceanic lithosphere, which produces highly reduced $\mathrm{CH}_{4}$-bearing fluids after olivine alteration by reaction with infiltrating fluids. Here we report the first ever observed in situ diamond within olivine-hosted, $\mathrm{CH}_{4}$-rich fluid inclusions from low pressure oceanic gabbro and chromitite samples from the Moa-Baracoa ophiolitic massif, eastern Cuba. Diamond is encapsulated in voids below the polished mineral surface forming a typical serpentinisation array, with methane, serpentine and magnetite, providing definitive evidence for its metastable growth upon low temperature and low pressure alteration of oceanic lithosphere and super-reduction of infiltrated fluids. Thermodynamic modelling of the observed solid and fluid assemblage at a reference P-T point appropriate for serpentinisation $\left(350^{\circ} \mathrm{C}\right.$ and $\left.100 \mathrm{MPa}\right)$ is consistent with extreme reduction of the fluid to $\log f \mathrm{O}_{2}(\mathrm{MPa})=-45.3\left(\Delta \log \mathrm{OO}_{2}[\right.$ Iron-Magnetite $\left.]=-6.5\right)$. These findings imply that the formation of metastable diamond at low pressure in serpentinised olivine is a widespread process in modern and ancient oceanic lithosphere, questioning a generalised ultra-high pressure origin for ophiolitic diamond.

Received 6 June 2020 | Accepted 31 July 2020 | Published 10 September 2020

\section{Introduction}

The discovery of nano- to micrometre scale grains of diamond separated from ophiolitic rocks has recently attracted the attention of geoscientists due to its potential evidence for lithosphere recycling down to, or below, the mantle Transition Zone (e.g., Yang et al., 2007, 2015; Griffin et al., 2016). The earlier reports of diamond in nominally low pressure ophiolitic rocks date back to the early 1990s, when diamond was found in heavy mineral concentrates obtained from Tibetan ophiolites (Bai et al., 1993). These were initially considered to be due to contamination during sample preparation. The debate, however, rejuvenated after findings of other UHP minerals such as coesite together with super-reduced phases in many chromitites and associated peridotites of ophiolites worldwide (e.g., Griffin et al., 2016). Farreaching geodynamic models have been proposed based on the assumption that diamond growth took place at UHP conditions in these rocks (e.g., Barron et al., 1996; Xiong et al., 2019 and references therein). Recently, the finding of in situ diamond in chromite-hosted fluid inclusions from ophiolitic chromitites by Farré-de-Pablo et al., (2019a) provided the first evidence for empirical (Simakov et al., 2015, 2020), experimental (Simakov et al., 2008) and theoretical (Manuella, 2013; Simakov, 2018) work on low pressure growth of diamond. However, the debate on the natural origin of diamond continued (e.g., Farré-de-Pablo et al., 2019b; Massonne, 2019; Yang et al., 2019). In this regard, Litasov et al. (2019a,b) have recently claimed that most diamonds, if not all, from ophiolitic rocks are not natural but instead have a synthetic origin, and emphasised the need to identify diamond below the polished surface of the host mineral. In this study we report for the first time in situ diamond grains hosted below the polished surface of magmatic olivine from a low pressure gabbro sill of the upper mantle section of the Moa-Baracoa Ophiolitic Massif, eastern Cuba (Supplementary Information; Figs. S-1-S-4, Table S-1), where super-reduced phases formed during serpentinisation have been previously reported (PujolSolà et al., 2018). Diamond grains, which are also present in olivine of associated chromitite, occur in secondary inclusions within olivine. Our observations provide conclusive evidence for the natural formation of metastable diamond at low $\mathrm{P}$ $(<200 \mathrm{MPa})$ and low $\mathrm{T}\left(<350{ }^{\circ} \mathrm{C}\right)$ during serpentinisation of oceanic mafic and ultramafic rocks, and allow a word of caution

\footnotetext{
Department of Mineralogy, Petrology and Applied Geology, University of Barcelona, Martí i Franquès s/n, 08028 Barcelona, Spain

Department of Mineralogy and Petrology, University of Granada, Av. Fuentenueva s/n, 18071 Granada, Spain

Andalusian Earth Science Institute (IACT), Spanish Research Council (CSIC)-University of Granada, Av. de las Palmeras 4, 18100 Armilla, Spain

Institut de Nanociència i Nanotecnologia, IN2UB Facultat de Química, University of Barcelona, Diagonal 645, 08028 Barcelona, Spain

Instituto de Cerámica y Vidrio - CSIC. C. Kelsen, 5, Campus de Cantoblanco, 28049 Madrid, Spain

Institute of Geology, National Autonomous University of Mexico, Ciudad Universitaria, 04510 Ciudad de México, Mexico

Corresponding author (email: npujolsola@ub.edu)
} 
on the development of generalised geodynamic models of mantle convection and lithosphere recycling into the deep mantle based on diamond and super-reduced phases alone.

\section{Results}

We have studied approximately 150 inclusions (96 below the polished surface) in olivine from 5 gabbro thin sections and 16 inclusions (8 below the surface) hosted in olivine in chromitite (representative inclusions in Table S-2). The inclusions align along trails that extend across adjacent mineral grains and delineate healed fractures (Fig. 1a-d). The distribution of these trails is heterogeneous, with some olivine grains showing a high density of trails cross-cutting each other. Inclusions are typically spheroid, with sizes ranging between $<1 \mu \mathrm{m}$ and $14 \mu \mathrm{m}$ in diameter (Figs. 1a-d, S-2).

Diamond grains were identified with the characteristic Raman peak at $1330 \mathrm{~cm}^{-1}$ with a slight downshift from the typical band to $1326 \mathrm{~cm}^{-1}(\mathrm{n}=17$; Table S-2) lining the walls of inclusions (Fig. 1e-f). These very small (200-300 nm) diamond grains were better characterised by confocal Raman maps at different depths (Fig. 1e-h). Nanodiamond is usually associated with methane, serpentine (lizardite, polygonal serpentine, chrysotile), and magnetite (Fig. 1h). Daughter minerals include diopside, chlorite, graphite-like amorphous $\mathrm{C}$, and calcite (Table S-2, Fig. S-5). Brucite was not identified in any of the studied inclusions, similar to other locations (e.g., Sachan et al., 2007). However, brucite is a widespread product in olivine-hosted fluid inclusions in ophiolitic samples (e.g., Klein et al., 2019; Grozeva et al., 2020).

TEM observations of a thin foil extracted by focused ion beam (FIB) (Fig. 2a) reveal that nanodiamond is clearly surrounded by polygonal serpentine and associated with magnetite (Fig. 2b,c). The selected area electron diffraction (SAED) pattern of a grain a few hundreds of nanometres in size confirms its diamond structure (with a reciprocal distance of $5 \mathrm{~nm}^{-1}$ corresponding to the $\mathrm{d}_{111^{-}}$-spacing of $2 \AA$; Fig. $2 \mathrm{~d}$ ), while the corresponding electron energy loss spectrum (EELS) indicates that C-type is the diamond allotrope ( $\mathrm{sp}^{3}$-hybridised $\mathrm{C}$ atoms; Fig. 2e). No polishing debris was observed in the studied inclusions, suggesting no contamination during ion milling of the thin foil except for sublimated Pt used to protect the area. The observed pore space in the inclusions (Figs. 2a, S-6) was likely filled by methane, as indicated by Raman spectroscopy measurements (Table S-2).

Sub-surface fluid inclusions lack water and are dominated by methane (Table S-2), similarly to olivine-hosted fluid inclusions described by Klein et al. (2019). In chromitite, diamond grains have been found in 5 sealed fracture-filling inclusions within interstitial magmatic olivine. One inclusion studied by TEM (Fig. S-7) revealed a $<1 \mu \mathrm{m}$-sized diamond crystal coexisting with the super-reduced phase native $\mathrm{Si}$. In addition, $\mathrm{H}_{2}$ was identified by Raman spectroscopy in another inclusion (Table S-2). Nevertheless, the phase assemblages are similar to those of the studied inclusions in olivine from the associated gabbro, with serpentine and magnetite (Fig. S-4, Table S-2).

\section{Natural Origin of the Studied Diamond}

The natural vs. anthropogenic origin of ophiolitic diamond is a hotly debated topic. Whereas in other samples the natural origin of diamond has not been firmly proved (Massonne, 2019), here we provide several lines of evidence for a natural origin. Our most significant evidence is that diamond is hosted within olivine well below the mineral's polished surface (Fig. 1). Such an observation meets the basic requirements for in situ mineral grains, as suggested by Massonne (2019). Additional evidence includes: (1) that diamond was found within $\mathrm{CH}_{4}$-bearing fluid inclusions forming linear arrays (healed fractures) in olivine and surrounded by serpentine (Figs. 1-2), and (2) lack of polishing debris and/or resin artificially incorporated (e.g., Dobrzhinetskaya et al., 2014).

\section{Processes and Conditions for Diamond Formation}

The olivine-hosted inclusion trails represent fluids trapped in healed fractures. Fluid infiltration in oceanic lithosphere is commonly associated with sporadic deformation events that trigger an increase of porosity by (micro-)fracturing during cooling below the brittle-ductile transition of olivine (Klein et al., 2019). In this scenario, fluid-rock interaction changes from a general open system during initial infiltration to closed system micro-reactors once the inclusions are sealed. At the initial trapping pressure and temperature and during subsequent cooling, the trapped aqueous fluids react with the olivine walls of the inclusion, triggering a number of reactions that ultimately result in growth of hydrated minerals and changes in fluid composition. Comprehensive thermodynamic models of these processes in ultramafic and oceanic rocks (McCollom and Bach, 2009; Klein et al., 2019) show that below $\sim 350^{\circ} \mathrm{C}$ (at $<200 \mathrm{MPa}$ ) in the stability field of serpentine + brucite "serpentinisation" of the walls of olivine hosting fluid inclusions consumes $\mathrm{H}_{2} \mathrm{O}$ in the fluid and generates $\mathrm{H}_{2}$ through precipitation of $\mathrm{Fe}^{3+}$-rich phases, particularly magnetite, so that consumption of inorganic carbon $\left(\mathrm{CO}_{2}\right)$ and formation of abiotic $\mathrm{CH}_{4}$ takes place. In the 6 component system $\mathrm{MgO}-\mathrm{FeO}-$ $\mathrm{SiO}_{2}-\mathrm{C}-\mathrm{O}_{2}-\mathrm{H}_{2}$, the formation of phase assemblages made of serpentine, brucite, magnetite, diamond and $\mathrm{CH}_{4}$-fluid from an initial assemblage made of olivine and $\mathrm{H}_{2} \mathrm{O}-\mathrm{CO}_{2}$ fluid can be described by a number of linearly independent reactions. Assuming 11 phase components (Fo, Fa, Mag, Mg-Srp, Mg-Brc, $\mathrm{H}_{2} \mathrm{O}, \mathrm{CO}_{2}, \mathrm{CH}_{4}, \mathrm{H}_{2}, \mathrm{SiO}_{2}$ (aq), $\mathrm{C}$ abbreviations after Whitney and Evans, 2010) appropriate for the low temperature stage of reaction progress, and excluding magnesite for simplicity, the dimension of the reaction space is 5 . Among many, the following set of five linearly independent reactions obtained with the software CSpace (Torres-Roldán et al., 2000) describes the process (commonly used as coupled reactions during serpentinisation, e.g., Lamadrid et al., 2017; Klein et al., 2019):

$$
\begin{aligned}
& 2 \mathrm{Mg}_{2} \mathrm{SiO}_{4}(\mathrm{Fo})+3 \mathrm{H}_{2} \mathrm{O} \leftrightarrow \mathrm{Mg}_{3} \mathrm{Si}_{2} \mathrm{O}_{5}(\mathrm{OH})_{4}(\mathrm{Srp})+\mathrm{Mg}(\mathrm{OH})_{2}(\mathrm{Brc}) \\
& 3 \mathrm{Fe}_{2} \mathrm{SiO}_{4}(\mathrm{Fa})+2 \mathrm{H}_{2} \mathrm{O} \leftrightarrow 2 \mathrm{Fe}_{3} \mathrm{O}_{4}(\mathrm{Mag})+2 \mathrm{H}_{2}+3 \mathrm{SiO}_{2}(\mathrm{aq}) \\
& \mathrm{CO}_{2}+4 \mathrm{H}_{2} \leftrightarrow \mathrm{CH}_{4}+2 \mathrm{H}_{2} \mathrm{O} \\
& \mathrm{CH}_{4}+\mathrm{CO}_{2} \leftrightarrow \mathrm{C}(\mathrm{Dia})+2 \mathrm{H}_{2} \mathrm{O} \\
& 3 \mathrm{Mg}(\mathrm{OH})_{2}(\mathrm{Brc})+2 \mathrm{SiO}_{2(\mathrm{aq})}=\mathrm{Mg}_{3} \mathrm{Si}_{2} \mathrm{O}_{5}(\mathrm{OH})_{4}(\mathrm{Srp})+\mathrm{H}_{2} \mathrm{O}
\end{aligned}
$$

As a whole, this set of reactions (and any other independent set, provided that it contains all phase components considered) indicates that the hydration process of olivine triggers the formation of magnetite by oxidation of $\mathrm{Fe}^{2+}$ (from component fayalite), liberating $\mathrm{H}_{2}$ that ultimately favours the consumption of $\mathrm{CO}_{2}$ and the formation of $\mathrm{CH}_{4}$ and $\mathrm{C}$. A bulk mass balance can be obtained after combination of these reactions correspondingly multiplied by a given stoichiometric coefficient. The number of combinations is hence infinite, and combinations that yield zero brucite are possible. A defined mass balance can be calculated only if additional constraints are imposed, such as the bulk composition of the system as long as the relative contribution of the above reactions to the integrated mass balance is a function of the original compositions of olivine and fluid and the initial fluid-olivine ratio. For initial $\mathrm{H}_{2} \mathrm{O}$-rich fluid and olivine 



(d) $\quad Z=0 \mu m$
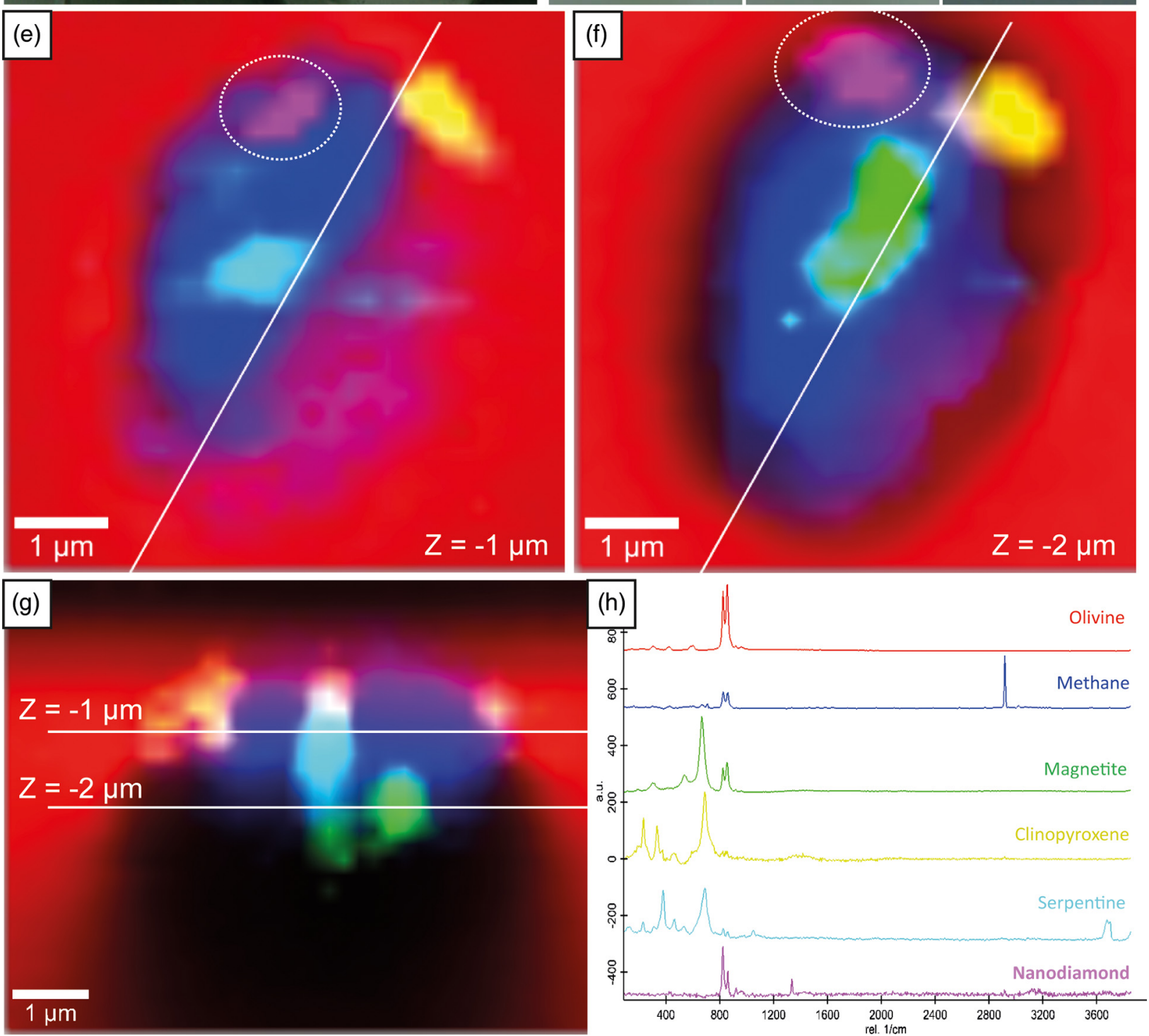

Figure 1 (a) Transmitted light photomicrograph (TLP) of olivine hosting a trail of secondary fluid inclusions. The red area defines the zoom in (b-d). (b, c) TLP of fluid inclusions below the surface of olivine with focus at $Z$ (depth) $=-1$ and $0 \mu \mathrm{m}$ respectively. (d) Reflected light photomicrograph of (c), showing that the central inclusion is completely below the surface. White rectangles mark the area of (e-g). (e) Fluid inclusion confocal Raman map at $Z=-1 \mu \mathrm{m}$; different colours represent different phases. (f) Confocal Raman map for the same inclusion at $Z=-2 \mu \mathrm{m}$. (g) Z-stack of (e,f) showing the inclusion profile. (h) Raman spectra of the identified phases (colour coded). Mapping conditions: $6 \times 6 \mu \mathrm{m}, 30 \times 30$ spectra, $\mathrm{T}_{\mathrm{int}}=2 \mathrm{~s}, 2 \mathrm{~mW}, 100 \times$ objective. 

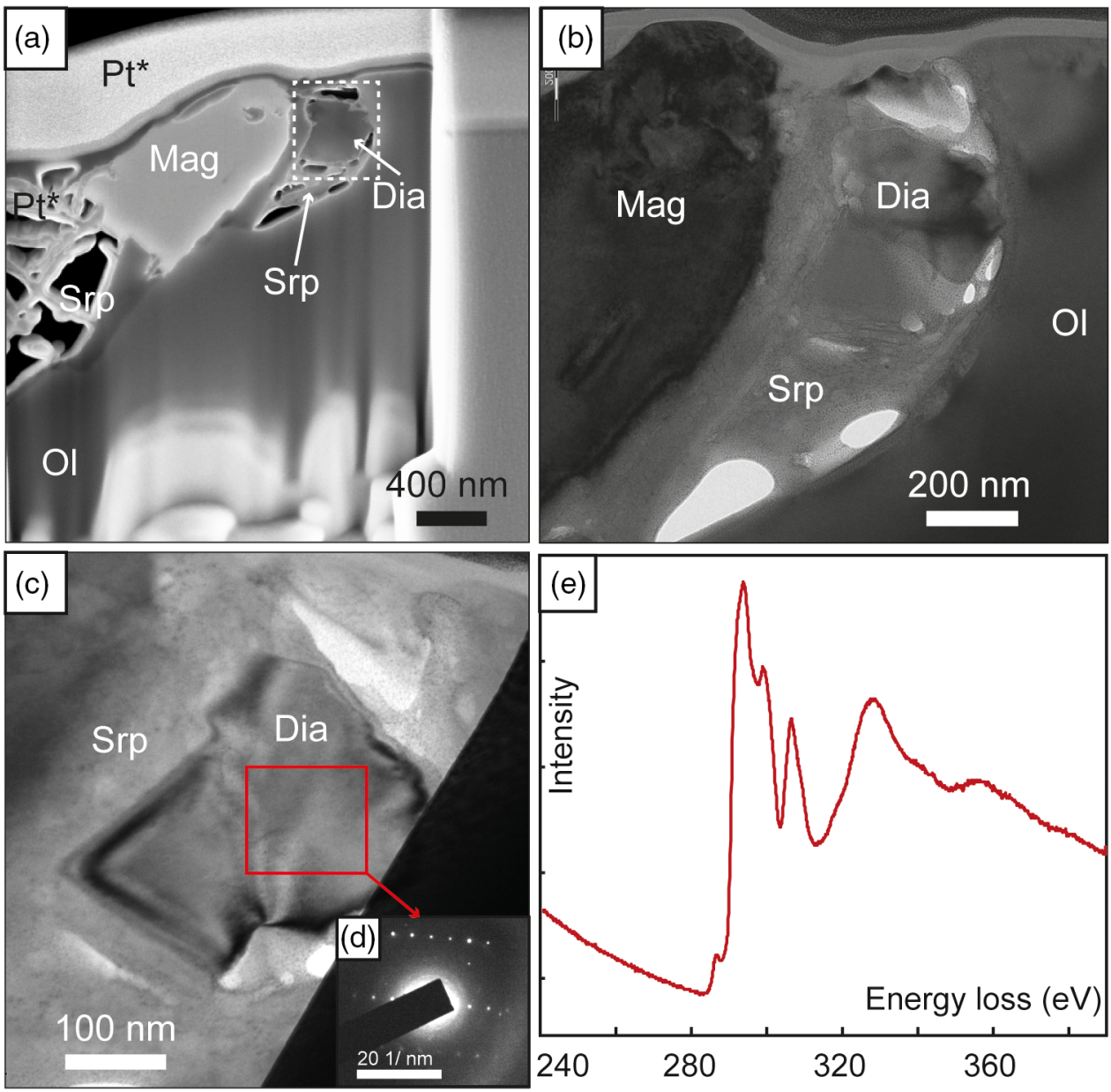

Figure 2 (a) Field emission scanning electron microscope image of olivine-hosted inclusion thinned by focused ion beam. (b,c) TEM image of the diamond and the surrounding serpentine and magnetite; the red square shows the selected area electron diffraction (SAED). (d) SAED pattern confirming the diamond structure of the crystal (the nearly horizontal rows of reflections have indices 111 with d spacing of $2 \AA$ ). (e) Electron energy loss near-edge structure of the C K-edge for the diamond showing a major peak due to its $\mathrm{sp}^{3}$ bonding. Abbreviations: Dia-Diamond, Mag-magnetite, Ol-olivine, Srp-serpentine, Pt*-platinum deposited during sample preparation.

with the composition of the studied gabbro (Table S-1), the observed stable brucite-lacking assemblage serpentine + magnetite + diamond $+\mathrm{CH}_{4}$-rich fluid can be reached for specific olivine-fluid ratios, such as in the following example obtained using the software CSpace:

$$
\begin{gathered}
0.272\left(\mathrm{Fo}_{74}-\mathrm{Fa}_{26}\right)+0.3\left(0.95 \mathrm{H}_{2} \mathrm{O}-0.05 \mathrm{CO}_{2}\right)=0.134 \mathrm{Srp} \\
+0.047 \mathrm{Mag}+0.004 \mathrm{SiO}_{2}+0.009 \mathrm{CH}_{4}+0.006 \mathrm{C}
\end{gathered}
$$

This reaction completely consumes both reactants. Under natural conditions in the fluid inclusion, olivine is in excess once $\mathrm{H}_{2} \mathrm{O}$ and $\mathrm{CO}_{2}$ are completely exhausted. Hence, thermodynamic calculations for a closed system fluid inclusion must consider an olivine-fluid ratio higher than $0.27: 0.3$. A bulk composition with an initial olivine:fluid ratio of $0.7: 0.3$ produces an assemblage of $51.3 \mathrm{vol}$ \% $\mathrm{Ol}(\mathrm{Fo}=0.76), 40.2 \mathrm{vol}$. \% antigorite, 6.8 vol. \% magnetite, 1.5 vol. $\% \mathrm{CH}_{4}$ and 0.12 vol. \% diamond at $100 \mathrm{MPa}$ and $350{ }^{\circ} \mathrm{C}$ using the Perple_X software (Connolly, 2009). According to the low $P$ conditions at which serpentinisation occurs, the stable $\mathrm{C}$ allotrope should be graphite. However, it has been demonstrated that nanodiamond can form at super-reducing conditions (e.g., Manuella, 2013; Simakov, 2018). Hence, in the above thermodynamic calculations, diamond has been used instead of graphite in order to simulate its metastable formation. The corresponding calculated $\log \left(\mathrm{fO}_{2} ; \mathrm{MPa}\right)$ is as low as $-45.3,\left(\Delta \log f \mathrm{O}_{2}[\right.$ Iron-Magnetite $]=-6.5$; Frost, 1991$)$, consistent with thermodynamic calculations in the diamond$\mathrm{COH}$ fluid system at $350^{\circ} \mathrm{C}$ and $100 \mathrm{MPa}$ (Fig. 3; cf. Schmidt et al., 2014).

Admittedly, calculations in a more complex system, with additional components and minerals (e.g., $\mathrm{CaO}$, clinopyroxene, talc, carbonates etc.) and constraints (e.g., dissolved silica in the fluid), and at other P-T conditions over which serpentinisation takes place, would yield a more intricate picture of the basic process outlined above and different absolute values of $\mathrm{fO}_{2}$ (e.g., Klein et al., 2019). However, a highly reduced environment (particularly at lower T, see e.g., Klein et al., 2019) should develop if $\mathrm{CH}_{4}$ is to be the main fluid species in the inclusions, making possible the metastable formation of nanodiamond in low pressure, olivine-bearing oceanic rocks during low $\mathrm{T}$ infiltration of $\mathrm{H}_{2} \mathrm{O}$ $\mathrm{CO}_{2}$ fluid mixtures.

The undoubted natural origin of diamond hosted with serpentine, magnetite and $\mathrm{CH}_{4}$ in sealed fluid inclusions within magmatic olivine from a gabbro sill and associated chromitite should be related to the generalised release of $\mathrm{CH}_{4}$ during hydrothermal alteration (partial hydration) of shallow oceanic lithosphere (e.g., Klein et al., 2019). This finding implies that the formation of nanodiamond in altered olivine-bearing rocks can be a widespread process. The presence of diamond (Farréde-Pablo et al., 2019a) and other highly reduced phases (e.g., metallic Si, moissanite; Pujol-Solà et al., 2018) in these rocks, in 


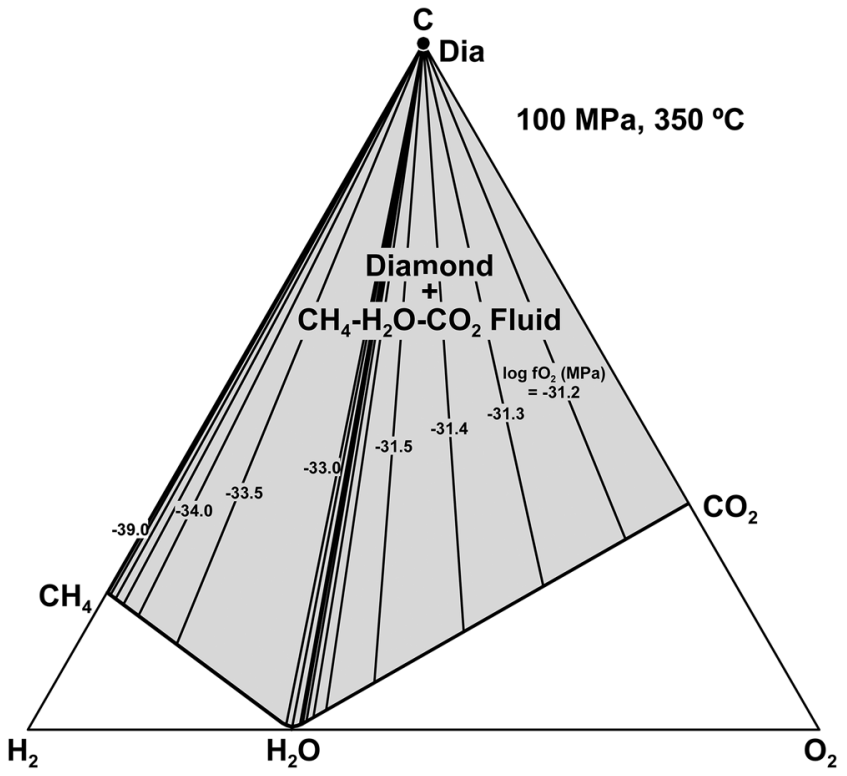

Figure 3 Phase relations in the $\mathrm{C}-\mathrm{O}-\mathrm{H}$ system (see methods in $\mathrm{SI}$ for details) with indication of $\mathrm{fO}_{2}$ isopleths (black solid lines, logunits) for the diamond-(Dia) saturated portion $(\log (\mathrm{aC})=0)$ of the system at $100 \mathrm{MPa}, 350{ }^{\circ} \mathrm{C}$.

particular chromitites, cannot hence be taken as a general indication of ultra-high pressure conditions (e.g., Yang et al., 2007, 2015; Griffin et al., 2016). The small size of diamond $(<1 \mu \mathrm{m})$ and its scarcity in the fluid inclusions are important handicaps in searching for "the needle in the haystack", thus explaining its apparent absence in other case studies of altered oceanic rocks.

\section{Acknowledgements}

We thank the editor H.R. Marschall and the reviewers F. Klein, I. Graham and C. Ballhaus for their constructive comments. This research was funded by Fondo Europeo de Desarrollo Regional (FEDER) Funds, Spanish Projects CGL2015-65824, RTI2018-099157-A-I00, PID2019-105625RB-C21, and A.RNM 186.UGR18. Additional funding was provided by the Ramón y Cajal Fellowship RYC-2015-17596 to JMGJ, a FPU-PhD grant to NPS, the Mexican research programs CONACYT-Ciencia Básica (A1-S-14574) and UNAM-PAPIIT grant IA-101419, and received support for analyses at CIC from the University of Granada.

Editor: Horst R. Marschall

\section{Additional Information}

Supplementary Information accompanies this letter at http:// www.geochemicalperspectivesletters.org/article2029.

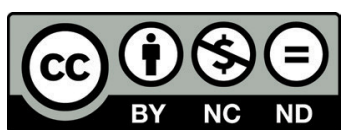

(C) 2020 The Authors. This work is distributed under the Creative Commons Attribution NonCommercial No-Derivatives 4.0 License, which permits unrestricted distribution provided the original author and source are credited. The material may not be adapted (remixed, transformed or built upon) or used for commercial purposes without written permission from the author. Additional information is available at http://www. geochemicalperspectivesletters.org/copyright-and-permissions.
Cite this letter as: Pujol-Solà, N., Garcia-Casco, A., Proenza, J.A., González-Jiménez, J.M., del Campo, A., Colás, V., Canals, À., Sánchez-Navas, A., Roqué-Rosell, J. (2020) Diamond forms during low pressure serpentinisation of oceanic lithosphere. Geochem. Persp. Let. 15, 19-24.

\section{References}

BAI, W.J., ZHOU, M.F., RoBinson, P.T. (1993) Possibly diamond-bearing mantle peridotites and podiform chromitites in the Luobusa and Donqiao ophiolites, Tibet. Canadian Journal of Earth Sciences 30, 1650-1659.

BarRon, L.M., Lishmund, S.R., OAKES, G.M., BARRON, B.J., SutheRLAND, F.L. (1996) Subduction model for the origin of some diamonds in the Phanerozoic of eastern New South Wales. Australian Journal of Earth Sciences 43, 257-267.

Connolly, J.A.D. (2009) The geodynamic equation of state: What and how. Geochemistry, Geophysics, Geosystems 10, doi: 10.1029/2009GC002540.

Dobrzhinetskaya, L., WirTh, R., Green, H. (2014) Diamonds in Earth's oldest zircons from Jack Hills conglomerate, Australia, are contamination. Earth and Planetary Science Letters 387, 212-218.

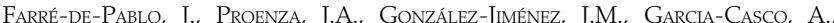
Colás, V., Roqué-Rosell, J., Camprubí, A., Sánchez-Navas, A. (2019a) A shallow origin for diamonds in ophiolitic chromitites. Geology 47, 75-78.

Farké-de-Pablo, J., Proenza, J.A., González-Jiménez, J.M., Garcia-Casco, A., Colás, V., Roqué-Rosell, J., Camprubí, A., SÁnchez-Navas, A. (2019b) A shallow origin for diamonds in ophiolitic chromitites: REPLY. Geology 47, e477-e478, doi: 10.1130/G46602Y.1.

Frost, B.R. (1991) Introduction to oxygen fugacity and its petrologic importance. Reviews in Mineralogy and Geochemistry 25, 1-9.

Griffin, W.L., Afonso, J.C., Belousova, E.A., Gain, S.E., Gong, X.H., GonZÁlezJiménez, J.M., Howell, D., Huang, J.X., McGowan, N., Pearson, N.J., Satsuawa, T., ShI, R., Williams, P., Xiong, Q., Yang, J.S., Zhang, M., O’Reilly, S.Y. (2016) Mantle Recycling: Transition Zone Metamorphism of Tibetan Ophiolitic Peridotites and its Tectonic Implications. Journal of Petrology 57, 655-684.

Grozeva, N.G., Klein, F., Seewald, J.S., Sylva, S.P. (2020) Chemical and isotopic analyses of hydrocarbon-bearing fluid inclusions in olivine-rich rocks. Philosophical Transactions of the Royal Society A: Mathematical, Physical and Engineering Sciences 378, 20180431.

Klein, F., Grozeva, N.G., Seewald, J.S. (2019) Abiotic methane synthesis and serpentinization in olivine-hosted fluid inclusions. Proceedings of the National Academy of Sciences of the United States of America 116, 17666-17672.

Lamadrid, H.M., Rimstidt, J.D., Schwarzenbach, E.M., Klein, F., Ulrich, S., Dolocan, A., BODNAR, R.J. (2017) Effect of water activity on rates of serpentinization of olivine. Nature Communications 8, 1-9.

Litasov, K.D. Kagi, H. Voropaev, S.A, Hirata, T, OhfuI, H., Ishibashi, H, MaKinO, Y., BeKKer, T.B., Sevastyanov, V.S., Afanasiev, V.P., POKHILENKO, N.P. (2019a) Comparison of enigmatic diamonds from the Tolbachik arc volcano (Kamchatka)and Tibetan ophiolites: Assessing the role of contamination by synthetic materials. Gondwana Research 75, 16-27.

Litasov, K.D., Kagi, H., BeKKeR, T.B., Hirata, T., Makino, Y. (2019b) Cuboctahedral type $\mathrm{Ib}$ diamonds in ophiolitic chromitites and peridotites: the evidence for anthropogenic contamination. High Pressure Research 39, 480-488.

MANUELLA, F.C. (2013) Can nanodiamonds grow in serpentinite-hosted hydrothermal systems? A theoretical modelling study. Mineralogical Magazine 77, 3163-3174.

MAssonne, H.J. (2019) Comment: A shallow origin for diamonds in ophiolitic chromitites. Geology 47, e476, doi: 10.1130/G46459C.1.

McCollom, T.M., BACH, W. (2009) Thermodynamic constraints on hydrogen generation during serpentinization of ultramafic rocks. Geochimica et Cosmochimica Acta 73, 856-875

Pujol-Solà, N., Proenza, J., Garcia-Casco, A., González-JiméneZ, J., Andreazini, A., Melgarejo, J., Gervilla, F. (2018) An Alternative Scenario on the Origin of Ultra-High Pressure (UHP) and Super-Reduced (SuR) Minerals in Ophiolitic Chromitites: A Case Study from the Mercedita Deposit (Eastern Cuba). Minerals 8, 433, doi: 10.3390/min8100433.

SACHAN, H.K., MuKheRJeE, B.K., BodnAR, R.J. (2007) Preservation of methane generated during serpentinization of upper mantle rocks: Evidence from fluid inclusions in the Nidar ophiolite, Indus Suture Zone, Ladakh (India). Earth and Planetary Science Letters 257, 47-59.

Schmidt, M.W., GaO, C., Golubkova, A., Rohrbach, A., Connolly, J.A. (2014) Natural moissanite $(\mathrm{SiC})$ - a low temperature mineral formed from highly 
fractionated ultra-reducing $\mathrm{COH}$-fluids. Progress in Earth and Planetary Science 1, 27.

SiMAKOV, S.K. (2018) Nano- and micron-sized diamond genesis in nature: An overview. Geoscience Frontiers 9, 1849-1858.

Simakov, S.K., Dubinchuk, V.T., Novikov, M.P., Drozdova, I.A. (2008) Formation of diamond and diamond-type phases from the carbon-bearing fluid at PT parameters corresponding to processes in the Earth's crust. Doklady Earth Sciences 421, 835-837.

Simakov, S.K., Kouchi, A., Mel'NiK, N.N., Scribano, V., Kimura, Y., Hama, T., Suzuki, N., Saito, H., Yoshizawa, T. (2015) Nanodiamond finding in the hyblean shallow mantle xenoliths. Scientific Reports 5, 10765, doi: 10 1038/srep10765.

Simakov, S.K., Scribano, V., Mel'Nik, N.N., Barone, G. (2020) Sicilian serpentinite xenoliths containing abiotic organics with nanodiamond clusters as key model for prebiotic processes. Geoscience Frontiers (in press), doi: 10.1016/ j.gsf.2020.04.008

Torres-Roldán, R.L., Garcia-Casco, A., García-SÁnchez, P.A. (2000) CSpace: An integrated workplace for the graphical and algebraic analysis of phase assemblages on 32-bit Wintel platforms. Computers and Geosciences 26, 779-793.

WhitNEY, D.L., Evans, B.W. (2010) Abbreviations for names of rock-forming minerals. American Mineralogist 95, 185-187.

Xiong, F., Liu, Z., Kapsiotis, A., Yang, J., LenaZ, D., Robinson, P.T. (2019) Petrogenesis of lherzolites from the Purang ophiolite, Yarlung-Zangbo suture zone, Tibet: origin and significance of ultra-high pressure and other 'unusual' minerals in the Neo-Tethyan lithospheric mantle. International Geology Review 61, 2184-2210.

Yang, J.S., Dobrzhinetskaya, L., BaI, W.J., Fang, Q.S., Robinson, P.T., Zhang, J., Green, H.W. (2007) Diamond- and coesite-bearing chromitites from the Luobusa ophiolite, Tibet. Geology 35, 875-878.

Yang, J., Meng, F., Xu, X., Robinson, P.T., Dilek, Y., Makeyev, A.B., Wirth, R WiedenBECK, M., ClifF, J. (2015) Diamonds, native elements and metal alloys from chromitites of the Ray-Iz ophiolite of the Polar Urals. Gondwana Research 27, 459-485.

Yang, J., Lian, D., Robinson, P.T., Qiu, T., Xiong, F., Wu, W. (2019) Comment to: A shallow origin for diamonds in ophiolitic chromitites. Geology 47, e475, doi: 10.1130/G46446C.1. 